\title{
Uralica
Helsingiensia
}

\section{Lähivertailuja 18}

TOIMITTANEET

HELLE METSLANG

JA RIHO GRÜNTHAL

HELSINKI 2008 


\title{
Eestlased ja eesti keel Soomes
}

\author{
KRISTIINA PRAAKLI \\ Tartu ülikool
}

Soome Statistikaameti andmetel elas 2007. a. märtsi seisuga Soomes 17599 Eesti kodakondsusega inimest (vt. Tilastokeskus). Püsivalt Soomes elavad emakeelena eesti keelt rääkivad isikud moodustavad Soome eesti keelevähemuse.

Uue keelevähemusena on Soome eestlaskond seni huvi pakkunud ühiskonnateadlastele. Valminud on esimesed teaduslikud uurimused, milles põhiteemadena käsitletakse Soome välispäritolu elanikkonna (sh eestlaste) integratsiooni (Liebkind jt. 2004), eluolu (Pohjanpää jt. 2003; Paananen 2005), peresiseseid keelevalikuid, oma emakeele kasutusvõimalusi ja keelekasutusalasid (Liebkind jt. 2004; Pohjanpää 2003; Tarnanen - Suni 2005) ning kultuuride kokkupuuteid (Jaakkola 1999). Nimetatutele lisaks on Soome eestlaskonda ning eestlaste Soome emigreerumist käsitletud mitmetes uurimustes (Kulu - Kyntäjä 1998) ning artiklites (Kyntäjä 1997; Laanekask 2006). Üksikutes uurimustes ning artiklites on käsitletud ka täiskasvanute keelekasutust (Jääskeläinen 2002; Praakli 2007), laste kakskeelsust ning keeleomandamist (Hassinen 2002; Keränen 1999; Stahl 2002; Teiss 2005, 2006).

Artiklil on kaks eesmärki. Esimeseks eesmärgiks on anda lühiülevaade Soome eestlaskonna ajaloost 20. sajandi algusest tänapäevani. Vaatlen eestlaskonna suurust eri perioodidel, käsitlen eestlaskonna taaskujunemist pärast Nõukogude Liidu lagunemist ning puudutan põgusalt Soome eestlaste kultuuritegevust. Teiseks eesmärgiks on tutvustada Tamperest kogutud keeleainestikku (suulise kõne lindistused) ning kirjeldada täiskasvanueas Soome emigreerunud emakeelena eesti keelt 
rääkivate informantide keelekasutuse iseloomulikke jooni lähtuvalt erinevate koodivahetusilmingute esinemisest nende kõnes.

\section{Mõnda Soome eestlastest}

August Nigoli andmetel elas 1917. aastal Soomes alaliselt u. 2000 eestlast, neist 800 Helsingis, 400 Viiburis, 80 Kabböles ning ülejäänud teistes Soome piirkondades (Nigol 1918: 78). Välis-Eesti almanahhi Soome kirjasaatja andmetel elas 1920ndate lõpus Soomes u. 1500 eestlast, neist 300-400 Helsingis Samast allikast leiab Helsingi eestlaste kohta ka järgneva kirjelduse. (Välis-Eesti Almanak 1929: 25-26.)

Helsingi Eesti Seltsi liikmete arv kõigub saja inimese ümber. Paljud vanemad perekonnad on üle läinud Soome kodakondsusesse. Suurem osa eestlastest elatab oma peresid ja endid mitmesuguste käsitöödega. On ka väikeäri-omanikke. Käesoleval ajal on väheseks jäänud kõrgema haridusega Eesti element. Needki vähesed, kes siin olemas, on Eesti asjale kui kustunud lambid. Rohkesti eestlasi on abiellunud soomlastega ja perekonnakeeleks kujunenud Soome keel. Siin sündinud eestlaste lapsed on enamasti keele ja vaimu poolest soomestunud ja Eesti on muutunud neile võõraks ja tundmatuks maaks. Seltsil ei ole selleks jõudu jatkunud, et seda nähet kõrvaldada ja Eesti keelt-meelt päästa.

Soome statistika aastaraamatus (STV 1948) esitatud arvandmete põhjal näeme, et alates 1930ndatest aastatest on Eesti kodakondsust omavate isikute arv pidevalt kahanenud (vt. tabel 1). Tõenäoliselt on Eestisse tagasi mindud, mujale Euroopasse rännatud või taotletud Soome kodakondsust (arvandmed perioodil 1928-1944 Soome kodakondsuse saanute kohta vt. STV 1946: 80). 
TABEL 1. Eesti kodakondsust omavate isikute arv Soomes 1930-1944 (STV 1948: 6)

\begin{tabular}{|l|c|c|c|c|c|c|c|c|c|c|c|c|c|}
\hline Aasta & 1930 & 1931 & 1932 & 1933 & 1934 & 1935 & 1936 & 1937 & 1938 & 1941 & 1942 & 1943 & 1944 \\
\hline Arv & 1320 & 1154 & 776 & 821 & 687 & 681 & 636 & 607 & 556 & 425 & 350 & 361 & 277 \\
\hline
\end{tabular}

1945. aasta seisuga elas Soomes 207 Eesti kodakondsust omavat isikut (STV 1948: 6). Pärast 19. septembril 1944 Soome ja Venemaa vahel sõlmitud vaherahu olid Soomes viibinud eestlased sunnitud riigist lahkuma, kuna sinnajäänuid ähvardas väljaandmine Nõukogude Liidule (RahiTamm 2004: 8; Jürjo 1996: 6). ${ }^{2}$ Relvarahukokkuleppes olid artiklid, mis kohustasid Soomet vabastama kõik isikud, kes olid sõja ajal vangistatud liitlasi toetava tegevuse pärast, keelustama kõik fašistlikud ja „Hitlerimeelsed” organisatsioonid ning andma kõik sõjakurjategijad kohtu alla (Tuomioja 2006: 238). Pärast vaherahu sõlmimist septembris 1944, osalt juba enne seda siirdus suur osa Soomes olnud eestlastest kas legaalselt või illegaalselt Rootsi (Roiko-Jokela 1997; Moora - Uustalu 1973; Relvik 2003; Leskinen - Juutilainen 2006). Teise maailmasõja lõpus Soome jäänud eestlasi ning eesti soost sõjapõgenikke on väga vähe.

Siinkirjutaja hinnangul võib Soome eestlaskonna ja eesti keelevähemuse (taas)kujunemise alguseks lugeda 1990ndate algusaastaid. Alates Nõukogude Liidu lagunemisest on Soome eestikeelse elanikkonna arv lühikese ajaga mitmekordistunud. Kui 1990. a. elas Soomes 1394 eesti keelt emakeelena rääkijat, siis 1995. a. oli vastav arv juba 8710 ning 2004. aasta lõpus 13978 (STV 2005: 116-117). Eesti Statistikaameti andmetel on Soome siirdumise kõrgajaks olnud 1995. aasta, mil Soome emigreerus 1067 isikut. Järgnevatel aastatel on Soome emigreerunud keskmiselt 500 inimest aastas (vt. tabel 2).

\footnotetext{
$1 \quad$ Statistika puudub 1939. ja 1940. aasta kohta.

2 Saksa okupatsiooni ajal 1941-1944 põgenes Soome u. 6000 inimest, kellest 1600 tuli soomepoistena Eestisse tagasi (Rahi-Tamm 2004: 16).
} 
TABEL 2. Eestist välismaale lahkunute sihtriigid 1986-1999 (ESA 1999: 57; ESA 1995: 77)

\begin{tabular}{|l|r|r|r|r|r|r|r|r|r|r|}
\hline & 1986 & 1987 & 1988 & 1989 & 1990 & 1995 & 1996 & 1997 & 1998 & 1999 \\
\hline Soome & 535 & 137 & 168 & 70 & 139 & 1067 & 648 & 550 & 510 & 491 \\
\hline Saksamaa & 225 & 472 & 501 & 698 & 563 & 496 & 463 & 322 & 207 & 196 \\
\hline Rootsi & 5 & 44 & 47 & 42 & 27 & 81 & 74 & 60 & 62 & 55 \\
\hline USA & 4 & 7 & 42 & 78 & 30 & 230 & 231 & 262 & 203 & 147 \\
\hline
\end{tabular}

Eestlasi elab kõikides Soome maakondades. Rohkem kui pool Soome eestlaskonnast elab pealinnaregioonis ja selle lähimaakondades: Uusimaal 8101; Varsinais-Suomis 1336 ja Pirkanmaal 847 (STV 2005: 116-117). 2004. aasta lõpus elas Helsingis 4261 eesti keelt emakeelena rääkijat. Selle arvuga olid eestlased soome-, rootsi-, vene- ja somaalikeelse elanikkonna järel Helsingis viiendal kohal (Helsingin kaupungin tilastollinen vuosikirja 2005: 38).

Üldisemad Soome emigreerumise põhjused ning riigis viibimise alused on etniline tagasiränne, abiellumine Soome kodanikuga ning perede taasühinemine (vt. Pohjanpää jt. 2003: 55-56; Liebkind jt. 2004: 22). Kuna nii Eesti kui Soome meedia on viimastel aastatel pidevalt eesti tööjõu massilise Soome siirdumise probleeme käsitlenud, võib järeldada, et lühema- või pikemaajaliselt Soomes elavate ning töötavate eestlaste arv on pärast Eesti ühinemist Euroopa Liiduga (2004) hüppeliselt kasvanud. Soome tööministeeriumi hinnangul töötab Soomes praegu 10 000-12 000 Eestist pärit inimest (Eures 2006). Eesti ja Soome meedia töömigratsiooni kajastustele tuginevalt võib oletada, et suurenenud on nn pendelrände osakaal - tööl käiakse Soomes, kuid kodu on endiselt Eestis. Soomes elavate eestlaste tegelik arv on tõenäoliselt palju suurem kui artikli alguses esitatud 17 599, kuna Eesti kodanik ei vaja enam elamis- ja tööluba Soomes. Ja alati on ka neid inimesi, kes viibivad ja töötavad riigis illegaalselt.

Soome eestlaste kultuurielu olulise osa moodustavad kohalikud eesti seltsid. 1997. aasta oktoobris asutati Tampere Eesti Klubi (TEK, www. eestiklubi.fi). Lisaks klubitegevusele andis TEK välja neli korda aastas ilmunud eestikeelset väljaannet Eesti Leht (1997-2003; 2003-2004 nime 
all Binokkel). Klubi põhitegevuseks on eesti kultuuriürituste korraldamine ning tähtpäevade tähistamine, samuti lastele suunatud tegevuse ja eesti keele õppe organiseerimine. Soome eestlaste seltsid tegutsevad veel Kotkas (Kotka Eesti Selts), Turus (Turu kandi eestlased), Iisalmis (Iisalmi Eesti Selts), Oulus (Oulu Eesti Klubi), Lappeenrannas (Lappeenranna Eesti Selts) ning Helsingis (Ida-Helsingi Eesti Klubi Koit ja Helsingi Eesti Lastering). Seltside tegevus on jäänud peamiselt kohalikule tasemele: tüüpiliseks tegevuseks on eesti jõulupeo, Eesti Vabariigi aastapäeva, eesti lasteringi ja suvepäevade korraldamine (Soome Eestlaste Liit 2006). 2002. aasta novembris asutasid eri paikkondade eestlaste ühenduste esindajad Tamperes Soome Eestlaste Liidu (SEL).

\section{Keeleainestik ja informandid}

Vaatluse alla tulev keeleainestik on kogutud Tamperes ${ }^{3}$ 2001-2002 ning 2004-2006. Ainestiku moodustavad informaalsed intervjuud ja spontaansed vestlused (intervjuusid 20 tundi; spontaanseid vestlusi 3.5 tundi). Kõik lindistused on läbi viinud artikli autor.

Informantideks on 25 püsivalt Tamperes elavat eestlannat, kes moodustavad omavahel aktiivselt läviva suhtlusvõrgustiku, mille üheks pidepunktiks on Tampere Eesti Klubi. Kõik informandid on sündinud Eestis ning emigreerunud Soome täiskasvanueas (st. vanemana kui 18 eluaastat). Suurem osa informantidest (13) on emigreerunud Soome 1990. aastate esimesel poolel (1990-1995), 10 informanti perioodil 1995-1999; Nõukogude Liidu perioodil saabunuid on kaks (vastavalt 1986 ja 1987). Seega võib uurimuses osalenud isikuid nimetada esimese põlvkonna Soome eestlasteks. ${ }^{4}$ Informantidest 14 on abielus soomlasega; üheksa eestlasega; üks Suurbritannia ja üks Šveitsi kodanikuga. Informante ise-

\footnotetext{
3 Soome statistikaameti andmetel on püsivalt Tamperes elavate Eesti kodanike arv 477, maakonnas (Pirkanmaa) tervikuna 847 (STV 2005: 116-117). Eestlased moodustavad Venemaa kodanike järel suuruselt teise välispäritolu rühma.

$4 \quad$ Nimetan esimese põlve Soome eestlasteks 1990ndate alguses täiskasvanueas Soome emigreerunud, emakeelena eesti keelt rääkivaid isikuid. Soome eestlaste teise põlvkonna moodustaksid nende järeltulijad.
} 
loomustavad tihedad kontaktid teiste Tampere eestlastega ning suures osas eestikeelsed suhtlusvõrgustikud ja lähikontaktid, mida võib seletada kohaliku eestlaskonna arvukusega ning eestlaskonda koondava Tampere Eesti Klubi aktiivse ja stabiilse tegutsemisega alates 1997. aastast.

\section{Kakskeelsed Tampere eestlased}

Emakeel ja uue elukohariigi keel mängivad emigratsioonis olulist rolli elukohariigi vahetus toob kaasa keelelise repertuaari ümberstruktureerimise, uute keeleregistrite omandamise, muutused emakeele rollis, funktsioonides ja kasutusväljades (Lüdi 1992: 49; vt. ka Dabène - Moore 1995: 20-25). Elukohariiki vahetanud isik seisab silmitsi vajadusega omandada uue elukohariigi keel, et tunda ennast täisväärtusliku ühiskonna liikmena, saada paremad töövõimalused ning luua kontaktid enamusrühmaga. Samal ajal on oluline emakeele säilitamine, sellele kasutusvõimaluste leidmine ja loomine.

Tampere eestlaste igapäevaellu kuulub kaks keelt - oma emakeel ehk eesti keel ja uue elukohariigi keel ehk soome keel. Eesti keel omab uuritavas kogukonnas (ning ühiskonnas laiemalt) vähemuskeele mitteametlikku staatust. Tampere eesti kogukonna puhul on tegemist tüüpilise sisserännanute keelesituatsiooniga, kus oma emakeele kasutusvõimalused jäävad üldiselt mitteformaalsete keelekasutusväljade (pere, sugulased, suhtlusvõrgustikud) raamidesse (vt. Tarnanen - Suni 2005: 9-21; Johanson 1993: 197-198).

Tampere eestlased on kakskeelsed inimesed. Artikli autor lähtub kakskeelse isiku määratlemises kahe keele kasutuse kriteeriumist - kakskeelne on inimene, kes kasutab igapäevaelus kahte või rohkemat keelt (Auer 1984: 7; Myers-Scotton 2002: 1; Halmari 1997: 21-23; vt. ka de Klerk 2006; Grosjean 1982). Informantide keelelisse repertuaari kuulub kaks põhisuhtluskeelt - eesti ja soome keel, mis rühmasiseses ja -välises suhtluses võimaldab vähemalt kolme variandi kasutamist:

1) ainult eesti keel (nt. rühmasisestes vestlustes sama rahvusrühma esindajatega); 
2) ainult soome keel (nt. rühmavälistes vestlustes enamus- või mõne teise rahvusrühma esindajatega);

3) kasutusel on mõlemad keeled, mis vestluse jooksul vahetuvad sõltuvalt teguritest nagu vestlussituatsioon, vestluspartnerid, vestlusteema jne.

Rääkijad võivad keele valikul lähtuda keerukatest (suhtlus)strateegiatest ning erinevatest faktoritest, kaasa arvatud identiteet ja kaasvestleja suhteline prestiiž, ümbruskond ja teema; keelevaliku võivad tingida ka keelesisesed faktorid, näiteks sõnavaratühikud (Matras 2001: 5).

\section{Koodivahetus Tampere eestlaste suulises keelekasutuses}

Püsiv teiskeelses ümbruskonnas elamine peegeldub indiviidide emakeeles. Soome keele ainese esinemine eestikeelsetes vestlustes tuleneb rääkijate geograafilisest asukohast, neid ümbritsevast keskkonnast ning selle kultuurilistest ja sotsiaalsetest joontest - ühtlasi on see märk rühmadevahelistest kontaktidest ja vastastikusest suhtlusest. Koodivahetus, mida käsitan kahe või rohkema keele vahelduva kasutusena vestluses - nii lausete sees kui lausete vahel (Verschik 2004: 26; Myers-Scotton 2002: 3), on kakskeelsete indiviidide puhul loomulik keelekasutuse ilming ja ka Tampere eesti kogukond ei moodusta siinkohal erandit.

Järgnevas keeleainestiku tutvustuses tulevad vaatluse alla Tampere eestlaste suulises keelekasutuses avalduvad koodivahetuse ilmingud. Nagu sisserännanute keelekasutust käsitlevad uurimused kinnitavad (nt. Latomaa 1998; Lammervo 2005; Francescini 1998; Backus 1998), on esimese põlvkonna keelekasutuse iseloomulikuks tunnuseks L2-keele (enamuskeele) mõjude esinemine leksikaalsel tasandil, mida sõltuvalt uurijast nimetatakse kas koodivahetuseks, laenamiseks või interferentsiks. ${ }^{5}$

Esimese põlvkonna Tampere eestlaste suulises kõnes on soome keele osakaal minimaalne. Koodivahetus toimub enamasti lause sees

\footnotetext{
$5 \quad$ Koodivahetuse uurimustes kasutatavatest terminitest on andnud põhjaliku ülevaate Anna Verschik (2004: 25-45).
} 
(intrasentential code-switching). Vestluse põhikeeles (eesti keel) esinevad üleminekud soome keelele on hetkelised ning lühikesed. Sisestusteks (insertion) on tüüpiliselt üksiksõnad (substantiivid, verbid, adjektiivid), üksikutel juhtudel ka fraasid. Koodivahetus toimub enamasti lause lõpus, kus esitatakse uut informatsiooni (seda on oma ainestikus täheldanud ka Kovács 2001: 122 ning Frick 2003: 17-19, 84-85). Kiire ning sujuv koodivahetus on informantide kõnes ebaharilik. Kõikide koodivahetusjuhtude puhul on tegemist ühesuunalise koodivahetusega, kus kood vahetub rääkija emakeelest enamuskeelde ehk soome keelde. Helena Halmari hinnangul on ühesuunalisele koodivahetusele immigratsioonisituatsioonis (immigrant situation) lihtne seletus: oma (etnilise) rühma liikmetega rääkides kasutatakse emakeelt, kuhu vajadusel põimitakse lühemaid või pikemaid lõike L2st, sageli referatiivsetel eesmärkidel (Halmari 1997: 69-70).

Pieter Muyskeni mõistestikust lähtuvalt tähendab sisestus võõrelementide juhuslikku kasutust põhikeele raamides (Muysken 2000: 3, 60-96; vt. ka Halmari 1997: 42-55, 219-220; Backus 2004: 700-708, 2006: 262-264). Eesti keel on kõikide vestluste põhikeel, mis moodustab lause morfosüntaktilised raamid, millesse sisestuskeele leksikaalsed elemendid paigutatakse:

(1) 01 INF22: aga meil on meil on meil on niisugune (naerab) niisugune pakendivabrik=et noh

02 seal me saame pakid saame tuuakse Venemaalt, et vahel olen ma neile tõlkind nagu

$03 \mathrm{KP}: \quad$ vene keelest?

$04 \rightarrow$ INF22: vene keelest jah (naerab) need suured rekkakuskit on venelased.

[rekkakuskit ee veoautojuhid]

Paljud sisendkeele elemendid on paigutatud vestluse põhikeele morfoloogiasse (2). 
(2) 01 $\rightarrow$ INF22: maahanmuuttajatele on oma kool. Nad lähevad nagu sinna siis natukene nagu

02 harjutama ja siis öeldakse need oppetajad ütlevad siis kuna need lapsed võivad minna

$03 \quad$ õigesse kooli.

[maahanmuuttaja ee sisserännanu, immigrant]

Sõnaklassidest on lausesiseses koodivahetuses esikohal substantiivid, neile järgnevad verbid ja adjektiivid (vt. ka Halmari 1997: 55-58; Tierney-Rissanen 2004: 39; Backus 2006: 265). Pronoomenite osakaal on väga väike, neid esineb üksikutel juhtudel. Rohkelt esineb ka nimesid ja nimetusi (nt. kohanimed ning asutuste- ja meediaväljaannete nimed), mida kasutatakse samuti eesti keele morfoloogilisele struktuurile vastavalt:

(3) 01 $\rightarrow$ INF3: isegi Valkeakoski Sanomites kirjutati.

[ajaleht Valkeakosken Sanomat]

(4) 01 $\rightarrow$ INF22: on, arste on palju. Euroarstid, mis on siin Hämeenpuistos, seal on on eestlasi.

$02 \rightarrow \quad$ Ja üliopistollises sairalas on eestlasi $=$ ja. Küll neid on päris palju tulnud.

[yliopistollinen sairaala, ee ülikooli haigla]

Sisestuse iseloomulikuks jooneks on nende seotus teatud teemavaldkondadega, milleks ainestikus on uue asukohariigi kultuur ja ühiskond. Soome keelendite kasutus eestikeelses kõnes ilmneb peamiselt ühiskondlike teemade puhul, mille ühe allkategooriana eristuvad töö ja õpingutega seostuv ning muu informandi erialast tulenev sõnavara (nt. hallinto, yrittäjä, mestari, aliurakoitsija, liikevaihtoveronumero, varajäsen, monikulttuurinen työkoulutus, työkokeilu, työelämä, työpaikkakiusaaminen, gradu, yliopisto, laitos, ylioppilaskirjoitukset, kauppaoppilaitos, liiketalous jne). Teise suure rühma moodustavad kultuurispetsiifilised sõnad ( $p i k$ kujoulu, hiihtoloma, porkkanalaatikko, perunalaatiokko, mustamakkara, sima jne). 
Substantiivide esinemisrohkust kontaktsituatsioonis põhjendatakse kultuuriliste ning ühiskondlike erinevustega ning vajadusega täita leksikaalseid tühikuid emakeeles. Uues keskkonnas puutuvad rääkijad kokku asjadega, mis on sellele keskkonnale või kultuurile omased ning võtavad nende kirjeldamiseks kohalikust keelest hõlpsasti sõnu omaks (Romaine 1995: 56, vt. Hennoste 1998: 15-16). Ainestikus esinevate substantiivide puhul rõhutaksin eelkõige leksikaalsete tühikute täitmist soomekeelsete vastetega. Autori tähelepanekud lindistamisel lubavad koodivahetust pidada ka vahel teadlikult rakendatavaks kommunikatsioonistrateegiaks, millele viitavad metalingvistilised märkused ning kommentaarid sõna(de) tundmise, tähenduse ja kasutuse kohta. Näidet (5) võib pidada tüüpiliseks leksikaalse tühiku täitmiseks teise keele pakutavate võimaluste abil.

(5) 01 INF1: Ma ütlen sulle nüüd ühe sõna aga ma ei tea, kuidas ta on eesti keeles ja ma usun, et $02 \rightarrow$ eesti keeles on olemas selline sõna nagu aliurakoitsija.

$03 \mathrm{KP}: \quad \ddot{A} a ̈$

04 INF1: See tähendab seda $=$ et

05 KP: Mai oska // ei tea mis see võib eesti keeles olla. Kas see võib olla alltöövõtja // ei?

[aliurakoitsija, ee alltöövõtja]

Lausesisene koodivahetus on paljudel juhtudel markeeritud selgete katkestuskohtadena keelte vahel, samuti eelnevad koodivahetusele erinevad kõnetootmise märgid. Eneseväljenduses tekkivad probleemid edastatakse vestluspartneritele signaalide kaudu (nt diskursusepartiklid, pausid, täitjad, pikad silbid, kordamised, parandused), millele kaasvestleja reageeringut oodatakse (Lauttamus 1990: 27-28; Pyöli 1996: 299; vt. ka Halmari 1997; Frick 2003). Ainestikus on enimesinevateks märkideks diskursusepartiklid, pronoomenid ning pausid, mis osutavad teadlikule ja läbimõeldud koodivahetusele. Koodivahetusele eelnev kõneplaneerimisprotsess on informandist sõltuvalt soome- või eestikeelne (enamasti eestikeelne), millest sagedamini rakendatavad kombinatsioonid on järgmised: 
(6) siuke + paus + koodivahetus:

01 $\rightarrow$ INF15: käis mingi prrr külalis siuke (.) külalisohja(a)ja.

[ohjaaja, ee juhendaja]

(7) nagu + paus + koodivahetus:

$01 \rightarrow$ INF15: need said siis oma nagu (.) tuomio said kuskil.

[tuomio, ee karistus]

(8) $n i i(n) k u+$ paus + koodivahetus:

01 $\rightarrow$ INF3: niinku ma ütlen et (.) sorjetaan.

[syrjetään, ee diskrimineeritakse]

Esimese põlvkonna informantide kõnes esineb lausetevahelist koodivahetust ainult üksikutel juhtudel. See võib olla tingitud kahest asjaolust: esimese põlvkonna informantide suhtluskeel on rühmasisestes vestlustes valdavalt monolingvaalne eesti keel, mis on ka kõikide informantide emakeel. Samuti võib oletada indiviidide suuremat keeleteadlikkust ning Eesti- (ja eesti keele) identiteedi säilitamist ning sellest lähtuvalt rühmasisestes vestlustes teadlikku emakeele raamides püsimist.

\section{Koodivahetuse funktsioonidest}

Koodivahetuse puhul on täheldatavad nende erinevad funktsioonid vestluses (nt. Gumperz 1982; Auer 1995; Zabrodskaja 2005, 2006; eesti-soome koodivahetuse funktsioonidest Praakli 2007; Frick 2003). Ainestikus avaldub koodivahetus tsiteeringutes, kordustes, sõnumi täpsustamises, naljades ja keelemängus ning rõhutamises, mõnel juhul võib koodivahetust pidada ka teadlikult kasutatavaks vestlusstrateegiaks. Ühel ja samal koodivahetusel võib vestluses olla mitu funktsiooni ning sõltuvalt kontekstist on koodivahetust võimalik erinevat viisi tõlgendada (vt. Kovács 2001). Tõlgendamist toetavad koodivahetuse kõrval esinevad muud kontekstualiseerimisvihjed, teksti sisu, taustateave teema ja rääkijate kohta, kultuurikontekst ning (teiste) vastuvõtjate reaktsioonid (Frick 2003: 118; vt. ka Praakli 2007). Kuna artikli pikkus seab ainestiku vaatlusele oma piirid, vaatlen koodivahetuse funktsioonidest ainult refereerimist. 
Suuline kõne võib sisaldada rohkem või vähem selgeid märke selle kohta, et mingi osa tekstist on refereeritud ehk pärit teisest allikast. Referaat tähendab teiste isikute või rääkija enda varem esitatud kõne, kirjutise või mõtte paigutamist enda teksti osaks nii, et oma ja laenatu on selgelt üksteisest eristatavad (ISK: 1399; Kalliokoski 2005: 22; eesti keeles Hennoste 2000: 203). Koodivahetuse avaldumine tsiteeringutena ei ole juhuslik, vaid sellel on kindel funktsioon - teises keeles aset leidnud sündmuse või kõnesituatsiooni toomine vestlusesse (Kovács 2001: 113; Turunen 1997: 221-223; Frick 2003: 82-83).

(9) 01 INF15: No seda ma olen kuulnud just kaheksakümnendate alguses tulnud nendelt

02 $\rightarrow \quad$ eestlannadelt=et et kui nad tulid siis mees ütles et et (.) nüüd maassa nagu maan

tavalla et räägid soome keelt kui me oleme siin.

[maassa maan tavalla, ee maal maa kombel]

Intervjueerija ja informandi vestlusteemaks oli soomlaste suhtumine keelevähemustesse, sealhulgas eestlastesse. Informant edastab refereeringu kaudu tuttava eestlanna abikaasa suhtumise. Informant viitab teksti autori(te)le (olen kuulnud nendelt eestlannadelt; mees ütles) ning edastab sõnumi tähtsaima osa võimalikult autentsel kujul osaliselt soome keeles (maassa nagu maan tavalla). Siinkohal võib koodivahetuses näha kolme funktsiooni: 1) teise isiku refereerimine: maassa nagu maan tavalla; 2) algallika arvamuse edastamine: riigis tuleb riigi kombel rääkida soome keelt; 3) seisukoha rõhutamine: algallika arvamuse edastamisega eemaldab rääkija ennast öeldust, rõhutades, et see on kellegi teise seisukoht, mitte minu.

Koodivahetus on ainult üks informantide keelekasutuse tunnus. Ainestikus esineb rohkelt otsetõlkeid ( $\mathrm{sm}$ heikko itsetunto $=$ nõrk enesetunne), kompromissvorme (automekaanik; suusapiiri), eesti ja soome keele lähedasest sugulusest tulenevalt leksikaalsete elementide kasutamist, mis kuuluvad küll mõlema keele sõnavarasse, kuid omavad laiemat kasutust soome keeles (nt. tajuma, üleval hoidma = säilitama; esile tooma 
= välja tooma; läbi käima = läbi vaatama jne). Ka soome partiklite osakaal on suur (sagedasemad joo, niin, kyll(ä)), samuti esineb soomekeelseid fraseoloogilisi väljendeid.

\section{Kokkuvõte}

Artikli eesmärkideks oli anda lühiülevaade Soome eestlaskonna ajaloost 20. sajandi algusest tänapäevani ning kirjeldada põgusalt soome keele mõjusid, mis on iseloomulikud esimese põlvkonna Soome eestlastele (Tampere eesti kogukonnast valitud informantide näitel).

Soome eestikeelne elanikkond on pärast Nõukogude Liidu lagunemist mitmekordistunud. Soomes elab juba praegu ametlikel andmeil umbes 18000 Eesti kodanikku, kuid võib arvata, et Eesti kodanike tegelik arv on palju suurem. Erinevad allikad peavad eestlasi üheks kiiremini kasvavaks välispäritolu rühmaks Soomes. Uue keelelise vähemusena on Soome eestikeelne elanikkond seni huvi pakkunud peamiselt ühiskonnateadlastele, kuid kahe lähedase ja morfoloogiliselt rikka sugulaskeele kokkupuuted pakuvad põnevat uurimisainet ka keeleteadlastele.

Artikli teiseks eesmärgiks on kirjeldada Tamperest kogutud keeleainestikku ning selle kaudu esimese põlvkonna eestlaste suulises keelekasutuses avalduvaid koodivahetusjuhte. Nagu on uurimustes tõdetud (ja mida näitab ka ainestik), on esimese põlvkonna informantide põhisuhtluskeel eesti keel, mis sisaldab valdavalt ühesõnalisi sisestusi teisest kontaktkeelest. Soome keele ainese esinemine informantide suulises kõnes on enamasti tingitud vestlusteemast. Koodivahetusega täidetakse leksikaalseid tühimikke või osutub soome elemendi kasutamine ühel või teisel põhjusel vastavast eesti keele sõnast „paremaks”. Koodivahetusel on ka selged kommunikatiivsed ülesanded. 


\section{Kirjandus}

Auer, Peter 1984: Bilingual Conversation. Pragmatics and Beyond. An Interdisciplinary Series of Language Studies, 8. Amsterdam: John Benjamins.

Auer, Peter 1995: The pragmatics of code-switching. - Lesley Milroy \& Pieter Muysken (toim.), One speaker, two languages: cross-disciplinary perspectives on code-switching, 1k. 115-135. Cambridge: Cambridge University Press.

Backus, Ad 1998: The intergenerational codeswitching continuum in an immigrant community. - Guus Extra \& Ludo Verhoeven (koost.), Bilingualism and Migration, lk. 261-279. Berlin: Mouton de Gruyter.

Backus, Ad 2004: Turkish as an Immigrant Language in Europe. - Tej Bhatia \& William Ritchie (koost.), The Handbook of Bilingualism, 1k. 689-724. Oxford: Blackwell.

Backus, Ad 2006: Limits to modularity: The 'insertion ' of complex 'lexical' constructions in codeswitching. - Conxita Lleo (koost.), Interfaces on Multilingualism. Acquisition and representation, 1k. 261-279. Hamburg Studies on Multilingualism 4. Amsterdam/Philadelphia: John Benjamins.

Dabène, Louise - Moore, Danièle 1995: Bilingual speech of migrant people. - Lesley Milroy \& Pieter Muysken (koost.), One speaker, two languages: Cross-Disciplinary Perspectives on Code-Switching, lk. 17-45. Cambridge: Cambridge University Press.

de Klerk, Vivian 2006: Codeswitching, Borrowing and Mixing in a Corpus of Xhosa English. - The International Journal of Bilingual Education and Bilingualism 9:5, lk. 597-614.

ESA 1995 = Eesti statistika aastaraamat. Tallinn: Statistikaamet 1995.

ESA 1999 = Eesti statistika aastaraamat. Tallinn: Statistikaamet 1999.

Eures 2006 = Eures Eesti. http://www.eures.ee/6909 23.11.2006.

Francescini, Rita 1998: Code-Switching and the notion of code in Linguistics: Proposals for a dual focus model. - Peter Auer (koost.), Code-Switching in Conversation, lk. 51-76. London/New York: Routledge.

Frick, Maria Kristiina 2003: Kaksikielistä rääkkimistä - koodinvaihdosta tartonsuomalaisten sähköposti- ja kasvokkainkeskusteluissa. Pro gradu -tutkielma. Helsingin yliopiston suomen kielen ja kotimaisen kirjallisuuden laitos.

Grosjean, Français 1982: Life with Two Languages: An Introduction to Bilingualism. Cambridge: Cambridge University Press.

Gumperz, John 1982: Discourse Strategies. Cambridge: Cambridge University Press. 
Halmari, Helena 1997: Government and Codeswitching. Explaining American Finnish. Studies in Bilingualism Series 12. Amsterdam/Philadelphia: John Benjamins.

Hassinen, Sirje 2002: Simultaaninen kaksikielisyys. Läheiset sukukielet viro ja suomi rinnakkain. Oulun yliopiston suomen ja saamen kielen ja logopedian laitos. Acta Universitatis Ouluensis, Humaniora, B 43. Oulu: Oulun yliopisto.

Helsingin kaupungin tilastollinen vuosikirja 2005: Helsingfors stads statistiska årsbok. Jyväskylä: Gummerus Kirjapaino OY.

Hennoste, Tiit 1998: Väliseesti keelest. - Liina Lindström (toim.), Väliseestlaste keelest, lk 11- 36. Tartu: Tartu Ülikool.

Hennoste, Tiit 2000: Sissejuhatus suulisesse eesti keelde IV. - Akadeemia 12, 8, lk $1772-1806$.

ISK = Hakulinen, Auli; - Vilkuna, Maria - Korhonen, Riitta - Koivisto, Vesa Heinonen, Tarja Riitta \& Alho, Irja 2004: Iso suomen kielioppi. Helsinki: Suomen Kirjallisuuden Seura.

Jaakkola, Magdalena 1999: Maahanmuutto ja etniset asenteet. Suomalaisten suhtautuminen maahanmuuttajiin 1987-1999. Helsinki: Edita.

Johanson, Lars 1993: Code coping in immigrant Turkish. - Guus Extra, Ludo Verhoeven (koost.), Immigrant Languages in Europe, 1k. 197-221. Clevedone - Philadelphia - Adelaide.

Jääskeläinen, Inkeri 2002: Kun Suomi ja Viro kohtaavat: äännevariaatioita virolaismuuttajien puhesuomessa ja muuttajien kulttuurinen sopeutuminen. Lisensiaattityö. Helsingin yliopiston suomen kielen laitos.

Jürjo, Indrek 1996: Pagulus ja Nõukogude Eesti. Vaateid KGB, EKP ja VEKSA arhiividokumentide põhjal. Tallinn: Umara.

Kalliokoski, Jyrki 2005: Referointi ja moniäänisyys kielenkäytön ilmiöinä. Markku Haakana \& Jyrki Kalliokoski (toim.), Referointi ja moniäänisyys, lk. 9-44. Tietolipas 206. Helsinki: Suomalaisen Kirjallisuuden Seura.

Keränen, Mika 1999: Ühe eesti-soome kakskeelse lapse verbi aegade omandamine vanuses 1.11 3.0. Bakalaureusetöö. Tartu Ülikooli eesti ja soomeugri keeleteaduse osakond, eesti keele (võõrkeelena) õppetool.

Kovács, Magdolna 2001: Code-Switching and Language Shift in Australian Finnish in Comparison with Australian Hungarian. Åbo: Åbo Akademis Förlag.

Kulu, Hill - Kyntäjä, Eve 1998: Muuttonäkymät Venäjältä ja Baltian maista Suomeen. Siirtolaisuustutkimuksia A 20. Vammala. 
Kyntäjä, Eve 1997: Eestlased Soomes - akulturatsioonipsühholoogia ja etniline identiteet. - Hill Kulu (toim.), Eestlane olla... Eesti keele ja kultuuri perspektiivid, lk 60-70. Tartu: Tartu Ülikooli Kirjastus.

Laanekask, Heli 2006: Virolaiset Suomessa suomenvirolaisiksi. - Olga Haurinen \& Helena Sulkala (toim.), Tutkielmia vähemmistökielistä Jäämereltä Liivinrantaan. Vähemmistökielten tutkimus- ja koulutusverkoston raportti V, lk. 55-73. Universitatis Ouluensis, Acta B, Humaniora B 69. Oulu: Oulun yliopisto.

Lammervo, Tiina 2005: Language and culture cntact and attitudes among first generation Australian Finns. Brisbane.

Latomaa, Sirkku 1998: English in contact with „the most difficult language in the world": the linguistic situation of American living in Finland. - International Journal of the Sociology of Language 133, lk. 51-71.

Lauttamus, Timo 1990: Code-switching and Borrowing in the English of Finnish Americans in an Interview setting. Kielitieteellisiä tutkimuksia N:o 20. Joensuu University.

Leskinen, Jari - Juutilainen, Antti 2006: Jatko-sodan pikkujättiläinen. Helsinki: WSOY.

Liebkind, Karmela - Mannila, Simo - Jasinskaja-Lahti, Inga - Jaakkola, Magdalena - Kyntäjä, Eve - Reuter, Anni 2004: Venäläinen, virolainen, suomalainen. Kolmen maahanmuuttajaryhmän kotoutuminen Suomeen. Gaudeamus: Helsinki.

Lüdi, Georges 1992: Internal migrants in an multilingual country. - Multilingua. Journal of cross-cultural and interlanguage communication 11, lk. 45-75.

Matras, Yaron 2001: Language contact. - Jef Verschueren, Jan-Ola Östman, Jan Blommaert \& Chris Bulcaen (koost.), Handbook of Pragmatics, 1k. 1-14. Amsterdam: John Benjamins.

Moora, Rein - Uustalu, Evald 1973: Soomepoisid. Soomepoiste Klubi Torontos, JR200 Sõprusühing Stockholmis ja JR200 Koondis Göteborgis.

Muysken, Pieter 2000: Bilingual speech. Cambridge: Cambridge University Press.

Myers-Scotton, Carol 2002: Contact Linguistics. Bilingual Encounters and Grammatical Outcomes. Oxford: Oxford University Press.

Nigol, August 1918: Eesti asundused ja asupaigad Venemaal. Tartu.

Paananen, Seppo 2005: Maahanmuuttajien elämää Suomessa. Helsinki: Tilastokeskus.

Pohjanpää, Kirsi - Paananen, Seppo - Nieminen, Mauri 2003: Maahanmuuttajien elinolot. Venäläisten, virolaisten, somalialaisten ja vietnamilaisten elämää Suomessa 2002. Helsinki: Tilastokeskus. 
Praakli, Kristiina 2007: Mõnda eesti-soome koodivahetuse funktsioonidest ja nende tõlgendamisvõimalustest. - Raili Pool (toim.), Emakeel ja teised keeled V. Tartu Ülikooli eesti keele (võõrkeelena) õppetooli toimetised 6, lk 151-163. Tartu: Tartu Ülikooli Kirjastus.

Pyöli, Raija 1996: Venäläistyvä aunuksenkarjala: kielenulkoiset ja -sisäiset indikaattorit kielenvaihtotilanteessa. Joensuu: Joensuun yliopisto.

Rahi-Tamm, Aigi 2004: Inimkaotused. Teise maailmasõja järgsed massirepressioonid Eestis: allikad ja uurimisseis. Tartu: Tartu Ülikooli Kirjastus.

Relvik, Heino 2003: Mereväe soomepoisid. Soome Mereväes Teeninud Eestlaste Gild. Tallinn.

Roiko-Jokela, Heikki 1997: Suomen ja Viron suhteiden käännekohtia 18601991. - Heikki Roiko-Jokela (toim.), Virallista politiikkaa, epävirallista kanssakäymistä, 1k. 361-373. Jyväskylä: Gummerus Kirjapaino Oy.

Romaine, Suzanne 1995: Bilingualism. Oxford: Blackwell.

Stahl, Kai 2002: Suomen kielen vaikutusta kahden Suomessa asuvan virolaislapsen äidinkielisessä puheessa. - Maija Järvenpää \& Kirsti Siitonen (toim.), Matkalla toiseen kieleen. Viisi praktikumtyötä äidinkielen ja opittavan kielen siirtovaikutuksista. Opetuksen ja tutkimuksen apuneuvoja 4, 1k. 117133. Turku: Turun yliopiston suomalaisen ja yleisen kielitieteen laitos.

STV 1946 = Suomen tilastollinen vuosikirja 1944-45. Helsinki: Tilastollinen päätoimisto 1946.

STV 1948 = Suomen tilastollinen vuosikirja 1946-47. Helsinki: Tilastollinen päätoimisto 1948.

STV 2005 = Suomen tilastollinen vuosikirja 2005. Helsinki: Tilastokeskus 2005.

Zabrodskaja, Anastassia 2005: Vene-eesti koodivahetus Kohtla-Järve vene emakeelega algkoolilastel. Tallinna Ülikooli eesti filoloogia osakonna toimetised 6. Tallinn: TLÜ Kirjastus.

Zabrodskaja, Anastassia 2006: Vene-eesti koodivahetuse funktsioonid KohtlaJärve venekeelsete laste vestluses. - Helle Metslang, Margit Langemets \& Maria-Maren Sepper (toim.), Eesti Rakenduslingvistika Ühingu aastaraamat 2, lk 231-249. Tallinn: Eesti Keele Sihtasutus.

Tarnanen, Mirja - Suni, Minna 2005: Maahanmuuttajien kieliympäristö ja kielitaito. - Seppo Paananen (toim.), Maahanmuuttajien elämää Suomessa, lk. 9-21. Helsinki: Tilastokeskus.

Teiss, Kristiina 2005: Kristian virolais-suomalaista kaksikielisyyttä omaksumassa: koodien yhdistyminen ja keskustelustrategiat. Pro gradu -tutkielma. Tampereen yliopiston kieli- ja käännöstieteiden laitos, suomen kielen ja yleisen kielitieteen jaos. 
Teiss, Kristiina 2006: Suhtlusstrateegiad eesti-soome kakskeelsust omanadava lapse segakoodis. - Helle Metslang, Margit Langemets \& Maria-Maren Sepper (toim.), Eesti Rakenduslingvistika Ühingu Aastaraamat 2, lk 251269. Tallinn: Eesti Keele Sihtasutus.

Tierney-Rissanen, Sandra 2004: Mie sanoin että 'good for her': code-switching in the speech of five Finnish women living in Britain. Pro gradu -tutkielma. Helsingin yliopiston englannin kielen laitos.

Tilastokeskus. http://www.stat.fi/tup/suoluk/suoluk_vaesto.html 03.08.2007.

Tuomioja, Erkki 2006: Õrnroosa: Hella Wuolijoe ja Salme Dutti elu revolutsiooni teenistuses. Tallinn: Varrak.

Turunen, Mikko 1997: Nykyvatjan koodinvaihdosta. - Virittää 101, lk. 208-229.

Verschik, Anna 2004: Koodivahetus meil ja mujal. - Keel ja Kirjandus XLVII:1, lk. 25-45.

Välis-Eesti Almanak 1929 = Välis-Eesti Almanak I, 1929. Tallinn: Välis-Eesti Ühing.

\section{Keelenäidete esitus}

- Voorude algus tähistatakse intervjueerija puhul tähekombinatsiooniga KP, informantide puhul tähe- ja numbrikombinatsiooniga (INF3, INF13, INF23)

- Kõik read nummerdatakse $(01,02,03,04)$

- Analüüsitav keeleaines esitakse paksus kursiivkirjas (nt on maahanmuuttaja)

- Nool $\rightarrow$ tähistab analüüsitava keelendi asukohta

- Tõlked esitatakse sulgudes [ ] 